\title{
The Mediating Role of Distribution Kahn's Engagement: An Empirical Evidence of Salesforce in Indonesia
}

\author{
Muhammad AKOB ${ }^{*}$, Rezki ARIANTY** ${ }^{* *}$ Aditya Halim Perdana Kusuma PUTRA ${ }^{* * *}$ \\ Received: November 2, 2019 Revised: December 11, 2019 Accepted: December 18, 2019
}

\begin{abstract}
This study aims to explore the role of Khan's engagement dimension previous study in mediating the relationship between work-life balance and in-role and extra-role performance of salesforce. To measure the data, a quantitative approach conducted through a survey of the sales force in the financial services industry sector in Makassar City, Indonesia. We determine the sample by using purposive sampling technique, and a total of 188 salesforce respondents. SEM-PLS with the second-order model was applied to test the measurement model and the mediator role of the engagement. The results show that the engagement dimension fully mediates the effect of work-life balance on both in-role and extra-role performance direct or indirect effect. the findings in this study also address the great concern of both individuals and organizations that the antecedents of the work-life balance variable are fundamental reasons for improving performance. The results of this study indicate that the worklife balance program positively influences engagement. Overall, we can conclude that commitment not only serves as a means for employees to fulfill formal job requirements. This can also encourage them to take action that goes beyond the precise requirements of their work by presenting them physically, emotionally, and cognitively in the work environment.
\end{abstract}

Keywords: Work-life Balance, Engagement, In-role Performance, Extra-role Performance.

JEL Classification Code: I3, I0, M0

\section{Introduction}

Precisely the subject of this study involves a sample of the salesforce in Indonesia, where the existence of salesforce is fundamental, salesforce at a glance is considered to be in a situation that seems comfortable. A dynamic work environment and situation, meeting with many people at a glance, is regarded as a profession without burden, is deemed to be a more comfortable position than

${ }^{*}$ First Author. Associate Professor, Postgraduate Management Program, STIEM Bongaya, Indonesia.

Email: akob.kadir@gmail.com

**Assistant Professor, Department of Management, STIEM Bongaya, Indonesia.

${ }^{* * *}$ Corresponding Author. Assistant Professor, Department of Management, Faculty of Economics and Business, Universitas Muslim Indonesia, Indonesia [Postal Address: Jalan Tamalate 1 Tidung 4 Number 143, Makassar City, South Sulawesi, 90222, Indonesia] Tel. +62-822-9222-2243, Email: adityatrojhan@gmail.com

(c) Copyright: Korean Distribution Science Association (KODISA)

This is an Open Access article distributed under the terms of the Creative Commons Attribution NonCommercial License (https://creativecommons.org/licenses/by-nc/4.0/) which permits unrestricted noncommercial use, distribution, and reproduction in any medium, provided the original work is properly cited. the employees who work as staff in the company. However, the environment that is considered suitable and dynamic also holds a variety of pressures, one of which is a strict target, and the possibility to face various consumer rejections. Dynamics in the workplace and coupled with changes in employee demographics in the last few decades have caused imbalances at every level, so the critical need to understand the boundaries and interactions between an employee's work and personal life becomes substantial (Hayman, 2005). It can be concluded that one of the spearheads of the company's success lies in the involvement of salesforce to meet the company's targets to overcome market competition (Amoako \& Okpattah, 2018). In many studies and facts that work comfort factor is one of the most fundamental things that are so coveted for employees in addition to other professional supporting factors (Pan, Chan, $\mathrm{Xu}$, \& Yeung, 2019).

On the other hand, specifically that a reliable, loyal, and trusted salesforce is also the dream that many companies, including large-scale companies (Stamolampros, Korfiatis, Chalvatzis, \& Buhalis, 2019). The profession as a salesforce with intense unpredictable performance opens 
wide the gap of high-stress tension (Kirkcaldy, Trimpop, \& Cooper, 1997; Corrigan, O’Leary, Kroes, Farooq, Horgan, Calvert, \& O’Connor, 2019). These pressures can come from many directions both internal personal, social and locus of control mindset (Kusuma, Rina, \& Syam, 2018; Chang, Zhou, Wang, \& Heredero, 2017) or external factors such as the work environment and organization or competitor persuasion factors that persuade employees to move to another company (Jyoti \& Rani, 2019).

So, various disturbances can reduce employee involvement. Employee involvement has emerged as a way for an organization to measure the results of the investment they have spent on the development of human resources (Salanova, Agut, \& Peiro, 2005). The issue of employee engagement is becoming a principal focus of attention, given that employee engagement has a positive impact on the organization, because disengaged employees can cause a loss of productivity (Salanova et al., 2005; Cahill, McNamara, Pitt-Catsouphes, \& Valcour, 2015; Meiyani \& Putra, 2019). It was concluded that reduced productivity means eliminating profit opportunities and impacting employee reputation in the future, even on an ongoing basis (Kahn, 1990).

Academics and business organizations try to identify and formulate various strategies to encourage employee engagement optimally. Initiator Psychological employee involvement was first put forward by William Kahn (1990). Khan revealed that the employee engagement process means employees express and dedicate themselves physically, cognitively, and emotionally in the company where they work. Employee engagement as an essential instrument as a basic form of embryo loyalty to the company. The study of employee involvement in several studies is caused by the impact of burnout and employee welfare (i.e., Leiter \& Maslach, 1997; Nguyen, Kitaoka, Sukigara, \& Thai, 2018; Jackson, Walker, Wright, Wishart, $\&$ Moore, 2018).

Kahn (1990) describes the motivation given by companies that are following employee expectations; emotional expression is manifested in the form of role involvement. Conceptualization between employee engagement not only shows a positive relationship on job performance but also represents a comprehensive view of the employee's personality and character. Human resources experts use the employee engagement model to develop employees more effectively and efficiently, thereby creating more enormous organizational benefits and better corporate performance (Crabtree, 2005; Besieux, Baillien, Verbeke, \& Euwema, 2018). Involvement increases the quality of relationships between individuals and organizations and provides positive outcomes such as workplaces that support performance, satisfaction and productivity, in-role and extra-role performance (Kahn, 1990; Mulki \& Wilkinson,
2017).

Employees cannot be seen as limited to the elements of capital as shown in the aspects of ancient management, and the increasingly dynamic era requires management participation to make employees not only limited to the factors of production but as intangible assets that have immense value (Arfah \& Putra, 2019). One of the keys to the success of employee involvement is supported by the feeling of work-life balance that has been felt by employees. Where the concept of work-life balance means the balance of aspects of personal, family, spiritual, and social life, Unbalance can trigger excessive stress so that it can have an impact on employee saturation, which will undoubtedly lead to a process of employee engagement that is not optimal. The equilibrium between personal, professional, and social life is also becoming a unique problem today. Cahill et al. (2015) are one of the researchers whose studies are used as a reference for measuring work-life balance on job satisfaction and employee involvement.

Where Cahill et al. (2015) revealed several important indicators in measuring work-life balance, one of which is based on micro-economic indicators (house prices or rental houses, salary, and health). While Brown, Kim, and Faerman (2019) centralize work-life balance measurements based on work flexibility, employee social aspects, and the organizational culture of the company. A significant difference from the research of the two research results wherein the perspective of work-life balance, according to Cahill et al. (2015) is based on the concept of welfare and the view of microeconomics, whereas (Brown et al., 2019) assess work-life balance from social life and organizational culture. The comparison is quite striking in measuring the work-life balance between Cahill et al. (2015) and Brown et al. (2019) and this study is a measurement of work-life balance that emphasizes aspects of emotional feelings, spiritual and employee locus of control combined with the Hayman instrument (2015) and modification of devices from (Milliman, Gatling, \& Kim, 2018) which elements of the conditions of the spirituality of employees.

Objectively this study aims to analyze the relationship of engagement modeling, as has been stated by Khan in his previous study where employee engagement includes three aspects such as physical, emotional, and cognitive. By making the khan engagement variable a moderating variable to investigate the relationship between work-life balance, in-role, and extra-role performance salesforce. The expected results in this study can provide a picture of the relationship and role of the work-life balance that has been modified from the previous research can provide a more comprehensive explanation of empirical and theoretical employee improvement strategies. 


\section{Literature Review}

\subsection{Work-Life Balance}

Work-life balance first used in Britain in the late 1970s to determine the level of individual stability between work life and personal life. Previous literature also referred to it as work-family conflict and has been widely used in contemporary human resource management disciplines (Frone, 2003; Crooker, Smith, \& Tabak, 2002). Clark (2000) Defining work-life balance is the extent to which individuals are equally involved and equally satisfied with meeting work and family needs. Work-life balance includes several aspects, including; how long people worked when people worked and where people worked. Every organization is currently facing fierce competition, both nationally and globally, and hence, demands for employee performance are increasing. Standards of assessment at work level and attitude changes at the level of social life are the main attraction for organizations (Burke \& El-Kot, 2010). Some previous research has shown that people are more interested in organizations that offer family-friendly situation (Grover \& Crooker, 1995). Other benefits of work-life balance for organizations are reducing absenteeism and lateness, increasing productivity and organizational image, employee commitment, and loyalty was increasing retention of valuable employees, reducing overtime costs, and reducing staff turnover. Meanwhile, the benefits of work-life balance for employees have increased job satisfaction, higher job security, increased control of the work-life environment, reduced levels of work stress, and increasing physical and mental health.

\subsection{Engagement-Kahn's Perspective}

William Khan first introduced the term employee engagement in 1990 through ethnographic research methods that have produced grand theories. Kahn officially defines commitment as the simultaneous employment and expression of a person preferred self in a task, or the utilization of self of an organization's members for their work roles by using and expressing themselves, both physically, cognitively and emotionally while carrying out their tasks in the organization (Kahn, 1990). In engagement, organizational members make full use of themselves in the performance of active and complete work roles by directing personal energy to physical, cognitive, and emotional work (Bakker, 2011). The individuals involved are described as being fully psychologically present, attentive, feeling, connected, integrated, and focused on their roles. They are open to themselves and others, combined with work and others, and bring themselves sufficiently to be involved in various opportunities (Macey \& Schneider, 2008). Kahn explained that physical, cognitive, and emotional behavior are indicators of an employee's involvement. Engagement requires a share of the hands, head, and heart to produce maximum performance.

The concept of Kahn's engagement encourages personnel to allocate resources into performance and how these resources are consistently applied or improved (Gruman \& Saks, 2011). An employee who has a high level of involvement in the organization has an understanding and concern for the organization's operational environment, is enthusiastic at work, can work together with other employees, talks positively about the organization, and goes beyond organizational expectations. Engaged organizations have authentic strengths and values, with clear evidence of trust and fairness based on mutual respect, both of which have promises and commitments between companies and employees that are understood and fulfilled (Kumar \& Sia, 2012). On the other hand, employee involvement requires more optimal attention because it involves physical, cognitive, or emotional aspects for a person to be able to complete his task. In other words, although individuals can be involved, their involvement must be connected simultaneously, not partially (Kahn, 1990; Lemon \& Palenchar, 2018). Many studies have revealed that there is an intrinsic relationship between employee involvement, loyalty, and profitability (Bruneau, Swaen, \& Zidda, 2018; Milliman et al., 2018; Ruck, Welch, \& Menara, 2017).

\subsection{In-Role and Extra-Role Performance}

The performance divided into two concepts, namely inrole production, and extra-role performance (Sosik, Juzbasich, \& Chun, 2011; Mulki \& Wilkinson, 2017; Hui, Law, \& Chen, 1999). Researchers (i.e., MacKenzie, Podsakoff, \& Ahearne, 1998; Hsu, Shih, \& Li, 2017) have considered in-role and extra-role performance as a measure of performance that is substantially different. Still, its application has its advantages in the role of employee work.

The concept of In-role and extra-role performance was first coined by Katz and Kahn (1978), in-role performance refers to behavior that is related to the productivity of individuals and organizations, both directly and indirectly. In-role behaviors defined as activities that are expected from sales associates, as they are explicitly stated in job descriptions (Vey \& Campbell, 2004; Vigoda-Gadot, 2007). Whereas extra-role performance explains that this behavior is needed to complete work responsibilities using evaluation standards set by the organization, for example, performance ratings, quality, and quantity of performance (Zhu, 2013). Extra-role performance measurements have been developed using the Morrison Scale, and this scale is one of the sizes that have been refined. It has an excellent psychometric ability to measure the construct of extra-role 
performance (Vey \& Campbell, 2004; Robinson \& Morrison, 1995).

\subsection{Hypothesis Development}

It is important to emphasize that not many studies have measured work-life balance practices concerning employee involvement. Both of these topics are rather widely studied as independent concepts. However, the literature evidence shows that there is a clear path between work-life balance practices, involvement, employee satisfaction, and wellbeing. Work-life balance initiatives have an impact on employee perceptions about organizational support, which in turn influences job involvement and satisfaction (Haar, Russo, Sune, \& Ollier-Malaterre, 2014). Susi and Jawaharrani (2011) make strong statements about the impact of work-life balance on employee involvement and turnover intentions. Some of these statements form the research hypothesis:

H1: Work-life balance positively affects engagement.

Some research results also provide a statement that there is a strong influence between the work-life balance on inrole performance (Kim, 2014; Wayne, Matthews, OdleDusseau, \& Casper, 2019; Beauregard \& Henry, 2009; Balkin, Roussel, \& Werner, 2015; Jyoti \& Rani, 2019). However, Kim (2014), in his research, found an indirect relationship between work-life balance and in-role performance. So the research hypothesis reads:

H2: Work-life balance positively affects In-role performance.

H3: Work-life balance positively affects extra-role performance.

Saks (2006) argues that employee involvement has an impact on employee attitudes, intentions, and behavior. Employees involved in work feel motivated to make an effort needed for excellent performance. Tims, Bakker, and Xanthopoulou (2011) have concluded that in-role and extrarole performance have an impact on work engagement. Kahn (1990) Argues that the physical, cognitive, and emotional energy of meeting fosters the appearance of active and complete roles through extra-careful, interpersonal, innovative, and engaging behaviors. The statements of the results of previous studies form a hypothesis:

H4: Engagement positively affects in-role performance.

H5: Engagement positively affects extra-role performance.

Maslach, Schaufeli, and Leiter (2001), Saks (2006) and Karatepe (2011) state employee involvement mediates the relationship between several work factors and the organization and the work results of employees. In line with the argument of MacKenzie et al. (1998) that extra-role performance might have a fundamentally different relationship with work factors such as work attitude and role perception compared to in-role performance, we have hypothesized two different processes about the possible role of mediation in involvement in reward and recognition relationships with in-role and extra-role performance, as follows:

H6: Engagement mediates the relationship between worklife balance and in-role performance.

H7: Engagement mediates the relationship between worklife balance and extra-role performance.

Based on the arguments presented in the introduction, prior research, and literature review sections, the theoretical framework of this research can be formulated in the following diagrams (Figure1):

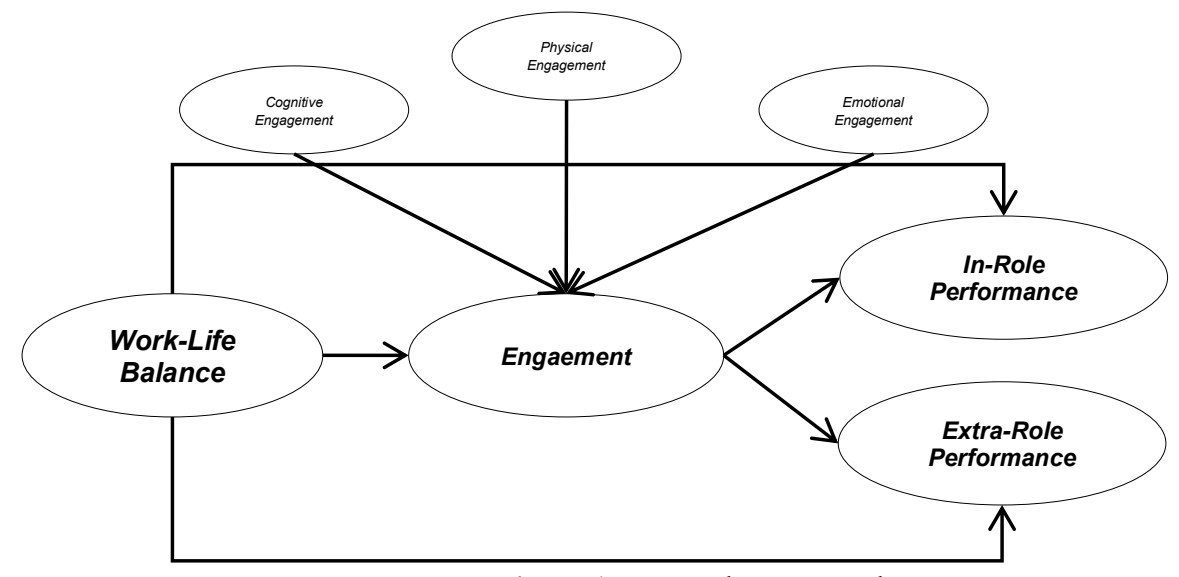

Figure 1: Research Framework 


\section{Research Methods and Materials}

\subsection{Samples}

Considering the total population of salesforce used as the object of research are 258 respondents with the criteria for selecting respondents with experience working as salesforce of at least 2 years, the sample category in this study is salesforce in the financial services industry in banking (credit card salesforce, financing, and insurance who collaborate with banks). The data collection method uses surveys, but from the results of data validity testing and outlier testing, as many as 70 respondents' data were declared invalid. So that the total sample available and valid and reliable data of 188 respondents. The period of the study starts from June - September 2019 in Makassar City, South Sulawesi Province, Indonesia. The demographic description of the respondents shows that the majority of respondents are women with an age range of 25-35 years and have worked for more than 3 years (Table 2). Most work in bank companies and finance with permanent employment status. From these demographic conditions, respondents are considered to have an appropriate profile to test the research construct.

\subsection{Measurement}

The measurement of the research variables described is illustrated in figure 1, explained in detail in Table 1.

Table 1: Variables, Items, and Sources of Constructs

\begin{tabular}{|c|c|c|}
\hline Construct & Items & Major References \\
\hline $\begin{array}{l}\text { Work-life Balance } \\
\qquad \text { (WLB) }\end{array}$ & $\begin{array}{l}\text { WLB1 - My personal life does not suffer because of work } \\
\text { WLB2 - I do not put my own life on hold for work } \\
\text { WLB3 - I do not miss my activities because of work } \\
\text { WLB4 - I do not struggle to juggle work and non-work } \\
\text { WLB5 - My personal life does not drain me of energy for work } \\
\text { WLB6 - I am not too tired to be productive at work } \\
\text { WLB7 - It is not hard to work because of personal matters } \\
\text { WLB8 - My job gives me the energy to pursue my activities } \\
\text { WLB9 - I have a better mood at work because of own life }\end{array}$ & $\begin{array}{c}\text { Hayman (2005), } \\
\text { Milliman, Gatling, \& } \\
\text { Kim (2018), Brown et } \\
\text { al. (2019) }\end{array}$ \\
\hline Engagement & $\begin{array}{l}\text { Physical Engagement (PE) } \\
\text { PE1 - I work with intensity on my job } \\
\text { PE2 - I exert my full effort to my job } \\
\text { PE3 - I strive as hard as I can to complete my job } \\
\text { Emotional Engagement (EE) } \\
\text { EE1 - I am enthusiastic in my position } \\
\text { EE2 - I am interested in my job } \\
\text { EE3 - I am proud of my job } \\
\text { Cognitive Engagement (CE) } \\
\text { CE1 - At work, my mind is focused on my job } \\
\text { CE2 - At work, I pay a lot of attention to my job } \\
\text { CE3 - At work, I focus a great deal of emphasis on my job }\end{array}$ & Khan (1990) \\
\hline $\begin{array}{l}\text { In-Role Performance } \\
\text { (IRP) }\end{array}$ & $\begin{array}{l}\text { IRP1 - Adequately completes assigned duties } \\
\text { IRP2 - Meets formal performance requirements of the job } \\
\text { IRP3 - Neglects aspects of the job he or she is obligated to perform } \\
\text { IRP4 - Fulfills responsibilities specified in the job description } \\
\text { IRP5 - Engages in activities that can positively affect his or her performance evaluation } \\
\text { IRP6 - Performs tasks that are expected of him or her } \\
\text { IRP7 - Consistently performs work tasks in a high-quality manner }\end{array}$ & $\begin{array}{l}\text { Turnley, Bolino, Lester, } \\
\text { \& Bloodgood (2003), }\end{array}$ \\
\hline $\begin{array}{c}\text { Extra-Role Performance } \\
\text { (ERP) }\end{array}$ & $\begin{array}{l}\text { ERP1 - Behavior helps certain people } \\
\text { ERP2 - Helps people outside the department when they have problems } \\
\text { ERP3 - Attendance, compliance with rules, etc. } \\
\text { ERP } 4 \text { - Arrives early so ready to work during work schedule } \\
\text { ERP5 - Refrain from activities complain and curse } \\
\text { ERP } 6 \text { - Don't exaggerate problems beyond their proportions } \\
\text { ERP } 7 \text { - Pay attention to organizational functions } \\
\text { ERP } 8 \text { - Help to arrange togetherness in a departmental } \\
\text { ERP } 9 \text { - Store information about events in an organization } \\
\text { ERP10 - Follow changes and developments in the organization }\end{array}$ & $\begin{array}{c}\text { Chen et al. (2014), } \\
\text { Griffin, Neal, \& Parker } \\
\text { (2007) }\end{array}$ \\
\hline
\end{tabular}


Where the work-life balance (WLB) variable as an Exogenous variable refers to the study of Hayman (2005) and Brown et al. (2019). Endogenous mediation variables use original measurements referring to a survey from Khan (1990) that includes Indicators of Emotional Engagement (EE), Cognitive engagement (CE), and physical engagement (PE). Endogenous In-Role Performance (IRP) variables refer to conceptual research from William and Anderson (1991). Another endogenous variable is ExtraRole Performance (ERP).

This study approach uses quantitative analysis methods, namely PLS-SEM. We use the PLS approach considering the conceptual in this study is the testing phase of the results of the modification of several research models so that the results of the development of the model can provide value descriptions and interpretations. Another reason for the use of PLS in this study is that the normality test is not expected. The Kolmogorov-Smirnov approach. $(\eta>0.5)$ While the test normality test, this study is $0.01<0.5$. The scale of measurement of variables using the Likert scale ( $1=$ Strongly Disagree $-5=$ Strongly agree). Analysis of software use Smartpls 3.0. Criteria for measuring variables and constructs are based on conditions such as AVE value $>$ 0.50 (Fornell \& Larcker, 1981), (Joe F Hair, Henseler, Dijkstra, \& Sarstedt, 2014). Value of Composite Reliability (CR > 0.6) (Chin, 1998). Measurement of Cronbach alpha value $>0.5$, R-square, F-Square, and measurement of loading-factors as the main formers of the variable (Chin, 1998). Before entering on the hypothesis test also through the two-structure model (second-order modeling) as shown in Figure 2.

Table 3: Measurement model assessment of first-order constructs

\begin{tabular}{|c|c|c|c|c|c|c|c|}
\hline First-Order Construct & Second-order construct & Items & Loadings & T Statistics & CR & Cut-off & AVE \\
\hline \multirow{7}{*}{ Work-life Balance } & \multirow{7}{*}{$\begin{array}{l}\text { Work-life } \\
\text { Balance }\end{array}$} & WLB1 & 0.844 & 29,312 & \multirow{7}{*}{0.928} & \multirow{7}{*}{0.909} & \multirow{7}{*}{0.648} \\
\hline & & WLB2 & 0.815 & 24,927 & & & \\
\hline & & WLB3 & 0.753 & 15,322 & & & \\
\hline & & WLB4 & 0.824 & 32,787 & & & \\
\hline & & WLB5 & 0.794 & 19,777 & & & \\
\hline & & WLB6 & 0.808 & 18,604 & & & \\
\hline & & WLB7 & 0.792 & 28,378 & & & \\
\hline \multirow{9}{*}{ Engagement } & \multirow{3}{*}{$\begin{array}{l}\text { Cognitive } \\
\text { Engagement }\end{array}$} & CE1 & 0.762 & 14,272 & \multirow{3}{*}{0.861} & \multirow{3}{*}{0.757} & \multirow{3}{*}{0.674} \\
\hline & & CE2 & 0.866 & 26,974 & & & \\
\hline & & CE3 & 0.832 & 20.857 & & & \\
\hline & \multirow{3}{*}{$\begin{array}{l}\text { Emotional } \\
\text { Engagement }\end{array}$} & EE1 & 0.743 & 10.833 & \multirow{3}{*}{0.842} & \multirow{3}{*}{0.724} & \multirow{3}{*}{0.641} \\
\hline & & EE2 & 0.780 & 12,522 & & & \\
\hline & & EE3 & 0.875 & 42,818 & & & \\
\hline & \multirow{3}{*}{$\begin{array}{l}\text { Physical } \\
\text { Engagement }\end{array}$} & PE1 & 0.849 & 21,356 & \multirow{3}{*}{0.789} & \multirow{3}{*}{0.705} & \multirow{3}{*}{0.562} \\
\hline & & PE2 & 0.810 & 15,964 & & & \\
\hline & & PE3 & 0.755 & 7,555 & & & \\
\hline \multirow{7}{*}{$\begin{array}{c}\text { In-role } \\
\text { Performance }\end{array}$} & \multirow{7}{*}{$\begin{array}{l}\text { In-role } \\
\text { Performance }\end{array}$} & IRP1 & 0.772 & 17,374 & \multirow{7}{*}{0.926} & \multirow{7}{*}{0.907} & \multirow{7}{*}{0.643} \\
\hline & & IRP2 & 0.828 & 27,683 & & & \\
\hline & & IRP3 & 0.838 & 30.437 & & & \\
\hline & & IRP4 & 0.847 & 38,207 & & & \\
\hline & & IRP5 & 0.795 & 26,017 & & & \\
\hline & & IRP6 & 0.737 & 19,518 & & & \\
\hline & & IRP7 & 0.790 & 28,888 & & & \\
\hline
\end{tabular}

\section{Results and Discussion}

\subsection{Data}

Table 2: Demographic Profile of Sales Force ( $\mathrm{N}=188)$

\begin{tabular}{|c|c|c|c|}
\hline Attribute & Item & F & $\%$ \\
\hline \multirow{2}{*}{ Gender } & Male & 68 & $36.1 \%$ \\
& Female & 120 & $63.9 \%$ \\
Age & $<25$ year & 53 & $28.2 \%$ \\
& $25-35$ year & 111 & $59.0 \%$ \\
& $>35$ year & 24 & $12.8 \%$ \\
Length of working & $1-3$ years & 31 & $16.4 \%$ \\
& $3-5$ years & 107 & $57.0 \%$ \\
Financial services & $>5$ years & 50 & $26.6 \%$ \\
company & Insurance & 33 & $17.6 \%$ \\
& Financing Bank & 62 & $33.0 \%$ \\
Types of employee & Permanent & 141 & $49.4 \%$ \\
& Non-permanent & 47 & $75.0 \%$ \\
& \multicolumn{2}{|c}{} \\
\hline
\end{tabular}

\subsection{First-Order Model Assesment}

Table 3 shows that the square root AVE of all constructs> 0.50 , the CR value also indicates a high enough amount of $>$ 0.80 . The value of the item loadings constructs $>0.60$ so that it is concluded that the feasibility test of the data is declared valid and reliable. The collinearity shown by the Variance Inflation Factor (VIF) must be below the cut-off point $<5$. As illustrated in Table 4 , the full collinearity value for all first-order constructions is below 5, and thus the discriminant validity is well established. 


\begin{tabular}{|c|c|c|c|c|c|c|c|}
\hline \multirow{9}{*}{$\begin{array}{c}\text { Extra-role } \\
\text { Performance }\end{array}$} & \multirow{9}{*}{$\begin{array}{l}\text { Extra-role } \\
\text { Performance }\end{array}$} & ERP1 & 0.894 & 48,051 & \multirow{9}{*}{0.950} & \multirow{9}{*}{0.941} & \multirow{9}{*}{0.680} \\
\hline & & ERP2 & 0.820 & 25,113 & & & \\
\hline & & ERP3 & 0.790 & 26,406 & & & \\
\hline & & ERP4 & 0.855 & 36,292 & & & \\
\hline & & ERP5 & 0.769 & 22,699 & & & \\
\hline & & ERP6 & 0.811 & 24,412 & & & \\
\hline & & ERP7 & 0.857 & 33,176 & & & \\
\hline & & ERP8 & 0.805 & 29,859 & & & \\
\hline & & ERP9 & 0.818 & 26,620 & & & \\
\hline
\end{tabular}

\subsection{Second-Order Model Assesment}

Following the second-order model approach, scores of latent variables from first-order constructs are used to construct formative second-order constructs. To establish a measurement model for second-order developmental construction, the Variance Inflation Factor (VIF) (Chin, 1998). The results presented in Table 4 show that the VIF value between the related items of each construction is lower than 5. Further findings reveal that the first-order construct significantly explains the second-order construct. Overall, the results showed that there were no problems with the conceptual overlap between constructs. Thus, the measurement model for second-order formative construction was confirmed.

Tabel 4: First-order constructs measurement

\begin{tabular}{|c|c|c|c|c|c|c|c|}
\hline & WLB & PE & EE & $\mathbf{C E}$ & IRP & ERP & VIF \\
\hline work-life balance (WLB) & $(0.805)$ & & & & & & 1.589 \\
\hline physical engagement (PE) & 0,694 & $(0.749)$ & & & & & 1.223 \\
\hline emotional engagement (EE) & 0,555 & 0,673 & $(0.801)$ & & & & 2.310 \\
\hline cognitive engagement (CE) & 0,618 & 0,709 & 0,602 & $(0.821)$ & & & 2.154 \\
\hline in-role performance (IRP) & 0,745 & 0,725 & 0,583 & 0,775 & $(0.802)$ & & 1.895 \\
\hline extra-role performance (ERP) & 0,758 & 0,656 & 0,606 & 0,685 & 0,774 & $(0.825)$ & 1.729 \\
\hline
\end{tabular}

Figure 2 shows an illustration of the contribution of items in shaping variables and indicators in the second-order model as a whole meeting the assumptions of previous research (Hair, Hult, Ringle, \& Sarstedt, 2017). Engagement variable as mediating variable with dominant Physical Engagement indicator formed by item (PE1), dominant Emotional Engagement indicator developed by item (EE3), and predominant Cognitive Engagement (CE) indicator created by item (CE2). The dominant work-life balance variable created by elements (WLB4). The variable relationship between Work-life balance on Engagement is 0.453 or $45.3 \%$. The dominant endogenous In-role performance variable formed by items (IRP4). The direct relationship between work-life balance is 0.189 or $18.9 \%$. While the relationship between engagement with in-role performance was 0.304 or $30.4 \%$, exclusively, it can be concluded that the systemic relationship between work-life balance and in-role balance mediated by Khan's engagement provides the optimal contribution. The dominant extra-role performance variable is formed by the item (ERP1), while the relationship between work-life balance and extra-role performance is 0.52 or $52 \%$. It can also be assumed that without mediation from work-life balance, engagement can reflect extra-role performance.

\subsection{Hypothesis Results}

Table 5 shows from seven hypotheses, dominant hypotheses are declared supported except the second hypothesis (H2), which explains the relationship between work-life balance variables on role performance (not supported).

Table 5: Hypothesis Result

\begin{tabular}{|c|c|c|c|c|c|}
\hline & Path Analysis & Loading & S.E. & T-stat & Result \\
\hline $\mathrm{H} 1$ & Work Life balance $\rightarrow$ Engagement & 0,453 & 0,109 & 4,156 & Support* \\
\hline $\mathrm{H} 2$ & Work Life Balance $\rightarrow$ In-Role Performance & 0,189 & 0,126 & 1,500 & Not Support \\
\hline $\mathrm{H} 3$ & Work Life Balance $\rightarrow$ Extra-Role Performance & 0,520 & 0,090 & 5,778 & Support** \\
\hline $\mathrm{H} 4$ & Engagement $\rightarrow$ In-Role Performance & 0,304 & 0,105 & 2,895 & Support* \\
\hline $\mathrm{H} 5$ & Engagement $\rightarrow$ Extra-Role Performance & 0,211 & 0,102 & 2,009 & Support* \\
\hline H6 & Work Life Balance $\rightarrow$ Engagement $\rightarrow$ In-Role performance & 0,419 & 0.068 & 6,161 & Support** \\
\hline $\mathrm{H} 7$ & Work Life Balance $\rightarrow$ Engagement $\rightarrow$ Extra-Role Performance & 0,370 & 0.087 & 4,252 & Support** \\
\hline
\end{tabular}

Sig: * $\alpha<0,05, * * \alpha<0,01$ 
In a direct relationship, an illustration of the relationship between work-life balance variables on extra-role performance shows the relationship (t-statistic), which is the biggest among the other immediate effects variables, namely 5.778, sig <0.01). Whereas in the indirect effect relationship (H6 and $\mathrm{H} 7$ ) where the sixth hypothesis shows the most significant effect ( $\mathrm{T}$ statistic $=6.161$, sig $<0.01$ ).

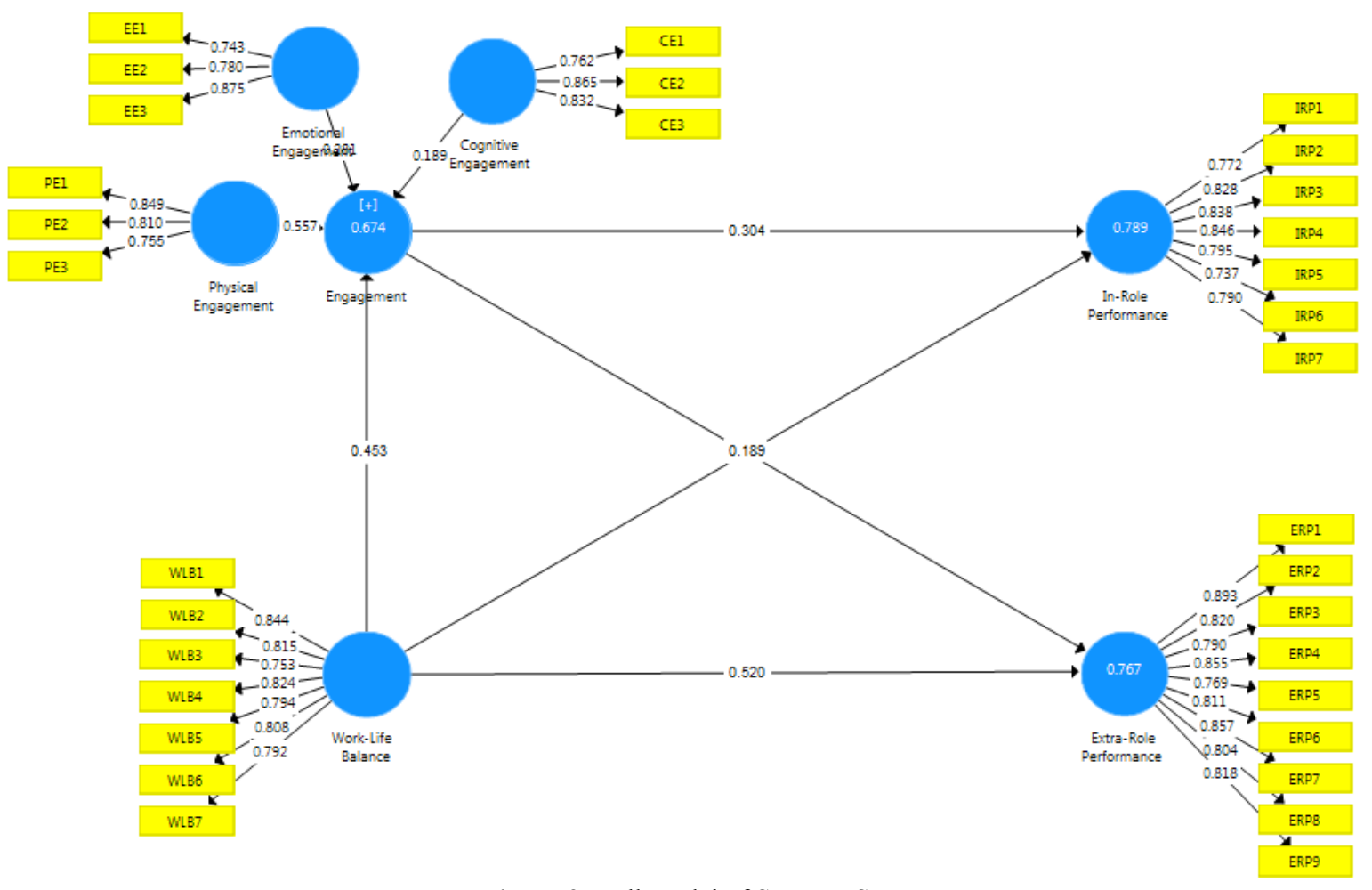

Figure 2: Full model of SEM-PLS

\section{Discussion}

The results of this study indicate that the work-life balance program positively influences engagement; Further involvement mediates the relationship between work-life balance, In-role, and extra-role performance. Overall, we can conclude that commitment not only serves as a means for employees to fulfill formal job requirements. But can also encourage them to take action that goes beyond the precise requirements of their work by presenting them physically, emotionally, and cognitively in the work environment. This study explains how the endogenous constructs, namely In-Role Performance, and extra-role performance, have different antecedents, where existing theories can be reconfirmed by linking the consequences of exogenous contracting effects (work-life balance and engagement). This finding is consistent with each previous research regarding the significant impact of work-life balance on engagement i.e., Susi and Jawaharrani (2011) as well as work-life balance on in-role performance and extra- role performance, as well as engagement on In-Role Performance and extra-role performance, i.e., Bakker (2011), Tims et al. (2011), and Saks (2006). The findings are contrary to the hypothesis, which explains that work-life balance has no significant effect on in-role performance. Thus it can be said that work activities that inhibit or support personal activities outside of work, and conversely, individual actions that hinder or support work activities are not able to increase employee in-role performance. An additional justification underlying this study is that other constructs are judged to have more influence on in-role performance, which is mediation from engagement.

The findings regarding involvement as a mediator in the relationship between work-life balance to in-role and extrarole are consistent with Saks (2006). Where involvement is a mediator between work-life balance variables and outcome variables such as extra-role performance, this study has complemented the literature by suggesting the 
role of intervention in regulating in-role and extra-role performance through the application of targeted work-life balance schemes. The results of this study also indicate that every work-life balance practice involving employees will increase in-role and extra-role performance. This study model scheme, which means salesforce will add value both in a theoretical and practical method. Besides, by outlining the causes behind the extra-role performance, this finding also enhances the understanding of antecedents of extrarole performance, which is still relatively under-explored in other studies considering that extra-role performance is as essential as a form of employee involvement and measurement of employee performance. Optimal employee engagement in a job is not only cognitive attention to the work itself, or to feel and express positive emotions at work, or to perform specific work tasks is limited to the completion of obligations as employees. Deeper than employee involvement reflects the simultaneous investment of cognitive, emotional, and physical energy so that employee personalities are actively and enthusiastically involved in a role in performance.

Theoretical Implication: The results of this study indicate that employee involvement is a meaningful construct that is feasible for future research. There are several avenues to consider. One area is to investigate other potential predictors of work and organizational involvement. This study includes several factors related to Kahn's involvement model (1990), Maslach et al. (2001) and Leiter and Maslach (1997).

Managerial Implication: In general, our results show that practices that engender engagement among employees can increase In-role and extra-role performance; this improvement may come in the form of task performance and organizational involvement behavior. However, despite the relevance of engagement with job performance has profound importance. The attention that is no less important to support involvement is also required to pay great attention to work-life balance. Involving salespeople through a balanced program between work and personal life to improve their performance at the level of in-role and extra-role is considered useful as a finding. Because this research has confirmed the hypothesized engagement mediation role, companies are required to recognize the efforts of employees and give them room to be more deeply involved based on internal policies. Furthermore, an appropriate and fair work-life balance program must be designed for performance outside the specified role also to increase extra-role performance. In this way, both in-role and extra-role performance can optimize by creating conditions that are motivating and conducive to creating employee involvement. Organizations must also encourage participation and feedback from employees to improve their ongoing engagement practices. Given that the limitations and shortages of skilled workers are one of the main challenges for salespeople managing an engagement program may be a useful tool for handling and retaining employees in this productive sector.

\section{Conclusion}

This study provides a comprehensive understanding of the importance of work-life balance to efforts to increase employee engagement. The meaning of life balance is not only limited to the fulfillment of financial and social needs. In this study, a balanced life approach that also emphasizes spiritual effects also has an impact on efforts to improve life balance at work. Khan elaborately describes the particle involvement of employees cognitively, physically, and emotionally still considered relevant. Fulfilling aspects of work-life balance not only reflects the fulfillment of performance in organizational activities but also shows its role in performance outside the primary duties of an employee. Maintaining the balance of life and work will undoubtedly reduce the stress level of employees while working.

\section{References}

Amoako, G. K., \& Okpattah, B. K. (2018). Unleashing salesforce performance: The impacts of personal branding and technology in an emerging market. Technology in Society, 54(8), 20-26. https://doi.org/https://doi.org/10.1016/j.techsoc.2018.01 .013

Arfah, A., \& Putra, A. H. P. K. (2019). Analysis of Productivity and Distribution of Female Workers in FB's Industries. Journal of Distribution Science, 17(3), 31-39. http://dx.doi.org/10.15722/jds.17.03.201903.31

Bakker, A. B. (2011). An Evidence-Based Model of Work Engagement. Current Directions in Psychological Science, 20(4), 265-269. https://doi.org/10.1177/0963721411414534

Balkin, D. B., Roussel, P., \& Werner, S. (2015). Performance contingent pay and autonomy: Implications for facilitating extra-role creativity. Human Resource Management Review, 25(4), 384-395. https://doi.org/https://doi.org/10.1016/j.hrmr.2015.07.00 1

Beauregard, T. A., \& Henry, L. C. (2009). Making the link between work-life balance practices and organizational performance. Human Resource Management Review, 19(1), 9-22. https://doi.org/https://doi.org/10.1016/j.hrmr.2008.09.001

Besieux, T., Baillien, E., Verbeke, A. L., \& Euwema, M. C. 
(2018). What goes around comes around: The mediation of corporate social responsibility in the relationship between transformational leadership and employee engagement. Economic and Industrial Democracy, $39(2)$, 249-271. https://doi.org/10.1177/0143831X15614914

Brown, H., Kim, J. S., \& Faerman, S. R. (2019). The influence of societal and organizational culture on the use of work-life balance programs: A comparative analysis of the United States and the Republic of Korea. The Social Science Journal, 1-11. https://doi.org/https://doi.org/10.1016/j.soscij.2019.03.0 08

Bruneau, V., Swaen, V., \& Zidda, P. (2018). Are loyalty program members really engaged? Measuring customer engagement with loyalty programs. Journal of Business Research, 91(Article in press), 144-158. https://doi.org/10.1016/j.jbusres.2018.06.002

Burke, R. J., \& El-Kot, G. (2010). Correlates of workfamily conflicts among managers in Egypt. International Journal of Islamic and Middle Eastern Finance and Management, 3(2), 113-131. https://doi.org/10.1108/17538391011054363

Cahill, K. E., McNamara, T.K., Pitt-Catsouphes, M., \& Valcour, M. (2015). Linking shifts in the national economy with changes in job satisfaction, employee engagement and work-life balance. Journal of Behavioral and Experimental Economics, 56(1), 40-54. https://doi.org/10.1016/j.socec.2015.03.002

Chang, X., Zhou, Y., Wang, C., \& Heredero, C.P. (2017). How do work-family balance practices affect workfamily conflict? The differential roles of work stress. Frontiers of Business Research in China, 11(1), 8. https://doi.org/10.1186/s11782-017-0008-4

Chen, Y., Shaffer, M., Westman, M., Chen, S., Lazarova, M., \& Reiche, S. (2014). Family role performance. Scale development and validation. Applied Psychology, 63(1), 190-218. https://doi.org/10.1111/apps.12005

Chin, W. (1998). The Partial Least Squares Approach To Structural Equation Modeling. Modern Methods for Business Research, 295(2), 295-336. https://doi.org/10.1016/j.aap.2008.12.010

Clark, S. C. (2000). Work-Family Border Theory: A New Theory of Work-Family Balance. Human Relations, 53(6), https://doi.org/10.1177/0018726700536001

Corrigan, L., O'Leary, C., Kroes, J., Farooq, A. R., Horgan, A., Calvert, P., \& O'Connor, M. (2019). Professional Burnout, Work Patterns and Career Satisfaction in Medical Oncologists In Ireland. Irish Journal of Medical Science, $\quad$ (1971), $1-8$. https://doi.org/10.1007/s11845-019-02088-3

Crabtree, S. (2005). Engagement Keeps the Doctor Away.
Gallup Management Journal, 13(1), 1-12.

Crooker, K. J., Smith, F. L., \& Tabak, F. (2002). Creating work-life balance: A model of pluralism across life domains. Human Resource Development Review, 1(4), 387-419. https://doi.org/10.1177/1534484302238434

Fornell, C., \& Larcker, D. F. (1981). Structural Equation Models with Unobservable Variables and Measurement Error: Algebra And Statistics. Journal of Marketing Research, 18(3) 382-388. https://doi.org/10.2307/3150980

Frone, M. R. (2003). Work-family balance. Handbook of Occupational Health Psychology (pp. 143-162). American Psychological Association, Washington DC. http://dx.doi.org/10.1037/10474-0077

Griffin, M. A., Neal, A., \& Parker, S. K. (2007). A New Model of Work Role Performance: Positive Behavior in Uncertain and Interdependent Contexts. Academy of Management Journal, 50(2), 327-347. http://dx.doi.org/10.5465/AMJ.2007.24634438

Grover, S. L., \& Crooker, K. J. (1995). Who Appreciates Family-Responsive Human Resource Policies: The Impact of Family-Friendly Policies on The Organizational Attachment of Parents and Non- Parents. Personnel Psychology, 48(2), 271-288. https://doi.org/10.1111/j.1744-6570.1995.tb01757.x

Gruman, J. A., \& Saks, A. M. (2011). Performance management and employee engagement. Human Resource Management Review, 21(2), 123-136. http://dx.doi.org/10.1016/j.hrmr.2010.09.004

Haar, J.M., Russo, M., Sune, A., \& Malaterre, A.O. (2014). Outcomes of work-life balance on job satisfaction, life satisfaction and mental health: A study across seven cultures. Journal of Vocational Behavior, 85(3), 361373. https://doi.org/10.1016/j.jvb.2014.08.010

Hair, J. F., Henseler, J., Dijkstra, T. K., \& Sarstedt, M. (2014). Common beliefs and reality about partial least squares: comments on Rönkkö and Evermann. Organizational Research Methods, 17(2), 182-209. https://doi.org/10.1177/1094428114526928

Hair, J.F., Hult, G.T.M., Ringle, C.M., \& Sarstedt, M. (2017). A Primer on Partial Least Squares Structural Equation Modeling (PLS-SEM) (2nd Edition). Thousand Oaks, CA: Sage Publications, Inc.

Hayman, J. (2005). Psychometric Assessment of an Instrument Designed to Measure Work Life Balance. Research and Practice in Human Resource Management, 13(1), 85-91.

Hsu, J. S. C., Shih, S. P., \& Li, Y. (2017). The mediating effects of in-role and extra-role behaviors on the relationship between control and software-project performance. International Journal of Project Management, $\quad 35(8), \quad$ 1524-1536. 
https://doi.org/10.1016/j.ijproman.2017.08.008

Hui, C., Law, K. S., \& Chen, Z.X. (1999). A Structural Equation Model of the Effects of Negative Affectivity, Leader-Member Exchange, and Perceived Job Mobility on In-role and Extra-role Performance: A Chinese Case. Organizational Behavior and Human Decision Processes, 77(1), 3-21. https://doi.org/https://doi.org/10.1006/obhd.1998.2812

Jackson, J., Walker, V.V., Wright, V.W.B., Wishart, P., \& Moore, S.L. (2018). Burnout and resilience in critical care nurses: A grounded theory of Managing Exposure. Intensive and Critical Care Nursing, 48(4), 28-35. https://doi.org/10.1016/j.iccn.2018.07.002

Jyoti, J., \& Rani, A. (2019). Role of burnout and mentoring between high performance work system and intention to leave: Moderated mediation model. Journal of Business Research, 98(2), 166-176. https://doi.org/https://doi.org/10.1016/j.jbusres.2018.12. 068

Kahn, W. A. (1990). Psychological Conditions of Personal Engagement and Disengagement at Work. The Academy of Management Journal, 33(4), 692-724. https://doi.org/10.2307/256287

Karatepe, O.M. (2011). Procedural justice, work engagement, and job outcomes: Evidence from Nigeria. Journal of Hospitality Marketing \& Management, 20(8), 855-878. https://doi.org/10.1080/19368623.2011.577688

Katz, D., \& Kahn, R. L. (1978). Organizations and the system concept (2nd edition, pp. 161-172). Hoboken, NJ: Willey.

Kim, H. K. (2014). Work-life balance and employees' performance: The mediating role of affective commitment. Global Business and Management Research, 6(1), 37-51. https://doi.org/10.1177/0972150916631071

Kirkcaldy, B. D., Trimpop, R., \& Cooper, C.L. (1997). Working hours, job stress, work satisfaction, and accident rates among medical practitioners and allied personnel. International Journal of Stress Management, 4(2), 79-87. https://doi.org/10.1007/BF02765302

Kumar, R., \& Sia, S. K. (2012). Employee engagement: Explicating the contribution of work environment. Management and Labor Studies, 37(1), 31-43. https://doi.org/10.1177/0258042X1103700104

Kusuma, A. H. P., Rina, R., \& Syam, A. H. (2018). The Main Role of Locus of Control and Professional Ethics on Lecturer's Performance (Indonesian Lecturer Empirical Study). International Review of Management and Marketing, 8(5), 9-17.

Leiter, M. P., \& Maslach, C. (1997). The Truth About Burnout: How Organizations Cause Personal Stress and What to Do About It (pp 1-200). Hoboken, NJ: Wiley.
Lemon, L. L., \& Palenchar, M. J. (2018). Public relations and zones of engagement: Employees' lived experiences and the fundamental nature of employee engagement. Public Relations Review, 44(1), 142-155. https://doi.org/https://doi.org/10.1016/j.pubrev.2018.01. 002

Macey, W.H., \& Schneider, B. (2008). The meaning of employee engagement. Industrial and Organizational Psychology, 1(1), 3-30. https://doi.org/10.1111/j.17549434.2007.0002.x

MacKenzie, S.B., Podsakoff, P.M., \& Ahearne, M. (1998). Some possible antecedents and consequences of in-role and extra-role salesperson performance. Journal of Marketing, 62(3), 87-98. https://doi.org/10.2307/1251745

Maslach, C., Schaufeli, W. B., \& Leiter, M. P. (2001). Job burnout. Annual Review of Psychology, 52(1), 397-422. https://doi.org/10.1146/annurev.psych.52.1.397

Meiyani, E., \& Putra, A. H. P. K. (2019). The relationship between islamic leadership on employee engagement distribution in FMCG industry: Anthropology business review. Journal of Distribution Science, 17(5), 19-28. http://dx.doi.org/10.15722/jds.17.05.201905.19

Milliman, J., Gatling, A., \& Kim, J. (2018). The effect of workplace spirituality on hospitality employee engagement, intention to stay, and service delivery. Journal of Hospitality and Tourism Management, 35(1), 56-65.

https://doi.org/https://doi.org/10.1016/j.jhtm.2018.03.002

Mulki, J. P., \& Wilkinson, J. W. (2017). Customer-directed extra-role performance and emotional understanding: Effects on customer conflict, felt stress, job performance and turnover intentions. Australasian Marketing Journal, 25(3), 206-214. https://doi.org/https://doi.org/10.1016/j.ausmj.2017.04.0 02

Nguyen, H. T. T., Kitaoka, K., Sukigara, M., \& Thai, A. L. (2018). Burnout Study of Clinical Nurses in Vietnam: Development of Job Burnout Model Based on Leiter and Maslach's Theory. Asian Nursing Research, 12(1), 42-49. https://doi.org/https://doi.org/10.1016/j.anr.2018.01.003

Pan, Y., Chan, S. H. W., Xu, Y., \& Yeung, K. C. (2019). Determinants of life satisfaction and self-perception of ageing among elderly people in China: An exploratory study in comparison between physical and social functioning. Archives of Gerontology and Geriatrics, 84(3), $1-9$. http://doi.org/https://doi.org/10.1016/j.archger.2019.1039 10

Robinson, S. L., \& Morrison, E. W. (1995). Psychological contracts and OCB: The effect of unfulfilled obligations on civic virtue behavior. Journal of Organizational 
Behavior,

$16(3)$

289-298.

http://dx.doi.org/10.1002/job.4030160309

Ruck, K., Welch, M., \& Menara, B. (2017). Employee voice: An antecedent to organizational engagement? Public Relations Review, 43(5), 904-914. https://doi.org/https://doi.org/10.1016/j.pubrev.2017.04. 008

Saks, A. M. (2006). Antecedents and consequences of employee engagement. Journal of Managerial Psychology, 21(7), 600-619. https://doi.org/10.1108/02683940610690169

Salanova, M., Agut, S., \& Peiró, J. M. (2005). Linking organizational resources and work engagement to employee performance and customer loyalty: the mediation of service climate. Journal of Applied Psychology, 90(6), 1217-1227. http://dx.doi.org/10.1037/0021-9010.90.6.1217

Sosik, J. J., Juzbasich, J., \& Chun, J. U. (2011). Effects of moral reasoning and management level on ratings of charismatic leadership, in-role and extra-role performance of managers: A multi-source examination. The Leadership Quarterly, 22(2), 434-450. https://doi.org/https://doi.org/10.1016/j.leaqua.2011.02. 015

Stamolampros, P., Korfiatis, N., Chalvatzis, K., \& Buhalis, D. (2019). Job satisfaction and employee turnover determinants in high contact services: Insights from Employees'Online reviews. Tourism Management, 75(4), 130-147.

https://doi.org/https://doi.org/10.1016/j.tourman.2019.0 4.030
Susi, S., \& Jawaharrani, K. (2011). Work-Life Balance: The key driver of employee engagement. Asian Journal of Management Research, 2(1), 474-483.

Tims, M., Bakker, A. B., \& Xanthopoulou, D. (2011). Do transformational leaders enhance their followers' daily work engagement? The Leadership Quarterly, 22(1), 121-131. https://doi.org/10.1016/j.leaqua.2010.12.011

Turnley, W. H., Bolino, M. C., Lester, S. W., \& Bloodgood, J. M. (2003). The impact of psychological contract fulfillment on the performance of in-role and organizational citizenship behaviors. Journal of Management, 29(2), 187-206. https://doi.org/10.1177/014920630302900204

Vey, M. A., \& Campbell, J. P. (2004). In-role or extra-role organizational citizenship behavior: Which are we measuring? Human Performance, 17(1), 119-135. http://dx.doi.org/10.1207/S15327043HUP1701_6

Vigoda, G.E. (2007). Redrawing the boundaries of OCB? An empirical examination of compulsory extra-role behavior in the workplace. Journal of Business and Psychology, 21(3), 377-405. http://dx.doi.org/10.1007/s10869-006-9034-5

Wayne, J. H., Matthews, R. A., Dusseau, O.H., \& Casper, W. J. (2019). Fit of role involvement with values: Theoretical, conceptual, and psychometric development of work and family authenticity. Journal of Vocational Behavior, 115(4), 103-317. https://doi.org/10.1016/j.jvb.2019.06.005

Zhu, Y. (2013). Individual behavior: In-role and extra-role. International Journal of Business Administration, 4(1), 23-27. https://doi.org/10.5430/ijba.v4n1p23 